\title{
ФОРМУВАННЯ ПРЕДМЕТНИХ МАТЕМАТИЧНИХ КОМПЕТЕНЦИЙ МОЛОДШИХ ШКОЛЯРІВ ЗАСОБАМИ ТРВЗ
}

Нікітіна О. О. Формування предметних математичних компетенцій молодших школярів засобами ТРВ3.

У статті розглянуто проблему формування предметних математичних компетенцій у молодших школярів. Розкрито значення нестандартних завдань для мотивації пізнавальної та пошукової діяльності учнів на уроках. Особливу увагу приділено технології ТРВЗ як одному із шляхів формування логічного мислення та розвитку творчого потенціалу учнів на уроках математики в початковій школі. Охарактеризовано зміст окремих методів ТРВ3 та наведені конкретні приклади завдань для учнів молодшого шкільного віку.

Ключові слова: компетентнісний підхід, предметні математичні компетенції, логічність мислення, творче мислення, технологія ТРВЗ.

Никитина Е. А. Формирование предметных математических компетенций младших школьников средствами ТРВ3.

В статье рассмотрена проблема формирования предметных математических компетенций у младших школьников. Раскрыто значение нестандартных задач для мотивации познавательной и поисковой деятельности учащихся на уроках. Особое внимание уделено технологии ТРИЗ как одному из путей формирования логического мышления и развития творческого потенциала учащихся на уроках математики в начальной школе. Охарактеризованы отдельные методы ТРИЗ и приведены конкретные примеры заданий для учащихся младшего школьного возраста.

Ключевые слова: компетентностный подход, предметные математические компетенции, логичность мышления, творческое мышление, технология ТРИЗ.

Nikitina Ye. A. The formation of mathematical competences of primary school pupils by means of TIPS.

In the article the problem of formation of mathematical competences of primary school pupils is descussed. The importance of nonstandard tasks for pupils' motivation and cognitive search activity at the lessons is shown. Particular attention is paid to TIPS technology as one of the ways of development of logical thinking and creativity of pupils at the Mathematics lessons at primary school. Some of TIPS methods are characterized and examples of tasks for primary school pupils are given.

Key words: competence-based approach, mathematical competences, logical thinking, creative thinking, TIPS technology.

Навчально-виховний процес у сучасній школі спрямований на досягнення такого рівня освіченості учнів, який був би достатнім для самостійного творчого розв'язання проблем теоретичного або прикладного характеру. Ця мета досягається шляхом організації розгорнутої, цілеспрямованої навчальної діяльності молодших школярів, 3 акцентом на формування навчально-дослідницьких умінь учнів, нестандартного, творчого мислення. Формування компетентностей учнів, їх здатностей мобілізувати знання в реальній життєвій ситуації - найактуальніша проблема сучасної початкової школи. 
Питання сутності компетентнісного підходу охарактеризоване дослідниками Н. Бібік, С. Клепко, О. Локшиною, О. Овчарук, О. Пометун, О. Савченко, А. Хуторським та ін. Специфіку формування предметних математичних компетенцій викладено в сучасних психолого-педагогічних дослідженнях Н. Листопад, Л. Кочиної, С. Скворцової. Теорію і практику ТРВ3 розглянуто в працях І. Дичківської, А. Купріхіна, Л. Макардіної, О. Онопрієнко,. У спеціальних дослідженнях В. Бухвалова, Б. Злотіна, С. Ладошкіної, А. Нестеренко та ін. розроблено серію методів і прийомів навчання школярів на основі ТРВ3.

Мета статті полягає у вивченні можливостей застосування теорії розв'язування винахідницьких задач на уроках математики для формування предметних математичних компетенцій учнів початкової школи.

Початковий курс математики - важливий складник навчання і виховання молодших школярів, основна частина математичної освіти. Навчання математики в початковій школі виконує низку значущих для загального розвитку особистості учня завдань, серед яких здатність логічно мислити та високий рівень інтелектуального розвитку, пам'яті, мовлення та уяви відіграють чи не найголовнішу роль під час формування предметних математичних компетенцій.

Структура змісту початкової освіти охоплює різні рівні знань про навколишній світ, способи пізнавальної і практичної діяльності, знання про людину, природу та суспільство; способи навчальної діяльності (уміння і навички); досвід творчої діяльності; цінності. Навчальною програмою 3 кожного предмета визначено державні вимоги до рівня загальноосвітньої підготовки учнів, що враховують зміст і структуру предметних компетентностей [6, с. 11].

3-поміж сучасних вимог до проведення уроків математики особлива увага звертається на забезпечення розвитку математичного мислення молодших школярів та формування в них досвіду творчої діяльності. Аналіз практики початкової математичної освіти свідчить про недостатній рівень спеціальної цілеспрямованої, системної методичної роботи, спрямованої на формування досвіду математичної діяльності молодших школярів. Як наслідок учні виконують математичні завдання програмного характеру, пишуть контрольні роботи 3 математики, але не можуть розв'язати задачу 3 логічним навантаженням чи виконати нестандартне математичне завдання. Засвоєння знань 3 математики в межах програми - це лише один із складників математичного розвитку учнів, який охоплює знаннєвий та операційний компоненти, тоді як інший передбачає творчий та емоційно-ціннісний складники початкової математичної освіти. На жаль, у більшості молодших школярів не розвинене творче мислення, вони не підготовлені до різноманітних видів роботи 3 навчальною інформацією, самостійного опрацювання математичних завдань, висунення оригінальних суджень та обгрунтування вибору способу дії [9, с. 74-75].

Характеризуючи компетентнісну спрямованість нових навчальних програм для початкової школи, О. Савченко зазначає, що найціннішим результатом початкової школи в особистісному вимірі є здорова дитина, мотивована на успішне навчання, дослідницьке ставлення до життя. Це учень, який уміє навчатися, користуючись різними джерелами, відповідально ставиться до себе й життя інших людей, усвідомлює себе громадянином України. Досягнення такого значущого результату початкової освіти, який має особистісне й соціальне значення, на думку дослідниці, потребує модернізації методики викладання кожного предмета на засадах суб'єктності навчання, створення сучасного навчальнорозвивального середовища, комфортного для дитини [7, с. 6].

Задля реалізації компетентнісного підходу в навчально-виховному процесі початкової 
школи застосовується проблемне навчання. У дослідженнях І. Ільницької особливу увагу приділено розробленню різних видів проблемних ситуацій, методиці підготовки та проведення уроків, а також вивченню впливу проблемних завдань на розвиток пізнавальної діяльності школярів. Дослідниця відзначає, що для організації процесу навчання виняткове значення має врахування психологічної структури проблемної ситуації. Це дає педагогам можливість впливати на всі сфери психіки учнів: емоційну, мотиваційно-вольову, інтелектуальну, які забезпечують ефективність виконання будь-якої діяльності, особливо пізнавальної, що сприяє творчому розвитку особистості [3, с. 46].

Український дослідник А. Фурман розглядає питання проблемного навчання з позиції психолого-педагогічних умов організації та ефективного використання проблемності в навчанні. У його працях особливу увагу приділено методиці застосування проблемних ситуацій на основі диференційованого підходу до учнів різних вікових груп. Проблемне навчання дослідник визначає як психолого-дидактичну систему змісту, методів, форм, засобів, умов і показників такого розвивального навчання, яке спричинює активне оволодіння учнями новими знаннями та способами дії у процесі індивідуального та спільного пошуку, забезпечує прискорене становлення їхніх пізнавальних потреб та інтересів, гармонійний розвиток творчого мислення, емоцій, волі [10, с. 44].

В умовах компетентнісно-діяльнісного підходу до змісту освіти та необхідності ефективної організації навчальної діяльності школярів перед школою постало важливе завдання - пошук шляхів формування навчально-дослідницьких умінь учнів. Пошукова активність виникає внаслідок нестандартної ситуації, яка вимагає розв'язання. Головна ознака нестандартної ситуації, яка активізує пошукову активність, - це об'єктивна неможливість задовольнити потреби особистості звичними, автоматизованими способами. Цей процес лежить в основі дослідницької поведінки [3, с. 15].

Обсяг навчального матеріалу 3 математики, необхідний для отримання знань, передбачає наявність високого рівня розвитку пізнавальних процесів молодшого школяра. Тому одним з найважливіших завдань вчителя початкової школи є створення умов, за яких дитина отримує можливість навчитися самостійно, критично та творчо мислити. Творча активність розвивається в процесі діяльності, яка змушує учнів пізнавати й дивуватися, знаходити рішення в нестандартних ситуаціях. Розв'язання проблеми розвитку творчих здібностей учнів на уроках математики можливе за умови застосування теорії розв'язання винахідницьких задач (ТРВ3), розробником якої є інженер Г. Альтшуллер. Це технологія, яка навчає нових прийомів винахідництва, має спеціальну галузь дослідження та свої методи розвитку творчості особистості. Основний зміст ТРВЗ полягає в усвідомленому перенесенні об'єктивно наявних закономірностей з однієї сфери життєдіяльності (технічної) на нову (навчальну) за допомогою розв'язання винахідницьких задач на основі логічних операцій, алгоритмів тощо [1].

Використання в навчальному процесі інтелектуальних інструментів ТРВ3 для розвитку творчого та системного мислення учнів допомагає успішно впоратися 3 поставленим завданням. Технологія ТРВ3 для молодших школярів - це технологія колективних ігор і занять з детальними методичними рекомендаціями. Такі форми роботи передбачають самостійний вибір дитиною теми, матеріалу та виду діяльності; вчать дітей виявляти суперечливі властивості предметів, явищ і усувати ці суперечності. Їх виявлення та розв'язання - ключ до творчого мислення.

Творчий інтелект дослідники розглядають як єдність і взаємодію емоційно-образного та логічного мислення, тому технологія на основі ТРВЗ передбачає системи тренувальних 
вправ для розвитку логічного мислення та творчої уяви. Вправи з логічним навантаженням сприяють створенню навчальних ситуацій, коли діти повинні порівнювати, узагальнювати, робити висновки, аналізувати. Вправи на розвиток творчої уяви вимагають від учнів самостійних рішень, пошуку власних шляхів розв'язування суперечностей, роботи за власним задумом, створення нових образів (мисленнєвих, реальних). Технологія ТРВ3 сприяє розвитку в учнів таких розумових здібностей, як-от: уміння аналізувати навчальну ситуацію, передбачати подальший iï хід, обгрунтовувати власні думки, оригінально, нестандартно мислити, вказувати на суперечності, розв'язувати математичні завдання, робити висновки [9, с. 75$]$.

Теорія розв'язування нестандартних задач заснована на принципі «звільнити мислення учнів від шаблонів» і передбачає підвищення культури та розвиток системності мислення. Часто на уроці вчитель говорить: «Порівняй», «Проаналізуй умову задачі», а дитина не знає, як це зробити. Це пояснюється тим, що учень не володіє на належному рівні цією мисленнєвою операцією, не розуміє точного значення дії, яку повинен виконати. Наприклад, дитина впевнено множить у стовпчик, коментує, яку цифру записує в якому розряді, а яку запам'ятовує. У школярів виникає запитання - «Чому робимо саме так, а не інакше?». Дитина розгублюється, адже вона оволоділа формою, а принцип розрядної дії лишився поза увагою. Незнання, нерозуміння теоретичних основ нумерації, математичних дій тощо, накопичується, і через деякий час знижується рівень знань, втрачається інтерес до навчання [4, с. 14-17].

Структура креативного уроку за методологією творчості відрізняється від традиційного уроку й містить блоки, які реалізують мету уроку:

Блок 1. Мотивація. Система зустрічей 3 дивовижними предметами, розгадування способів їх створення дозволяє забезпечити інтерес і продуктивність пошукової діяльності молодших школярів.

Блок 2. Змістовна частина. Містить програмний матеріал навчального курсу i забезпечує формування системного мислення та розвиток творчих здібностей з елементами конструювання.

Блок 3. Психологічне розвантаження. Цей блок забезпечує психологічне розвантаження для «відпочинку мозку».

Блок 4. Головоломка. Головоломки для школяра - це проблема, розв'язання якої вимагає від нього нетрадиційного мислення.

Блок 5. Інтелектуальна розминка. $\mathcal{C}$ системою ускладнених завдань, спрямованих на розвиток мотивації, логічного мислення та творчих здібностей учнів. Інтелектуальна розминка дозволяє забезпечити мотивацію учнів і залучити їх до творчої діяльності на уроці.

Блок 6. Змістовна частина. «Творча майстерня». Ця частина спрямована на розвиток творчої уяви і фантазї̈ учнів.

Блок 7. Комп’ютерна інтелектуальна підтримка. Забезпечує мотивацію і розвиток мислення, передбачає систему ускладнених комп'ютерних ігор-головоломок, адаптованих до віку учнів, забезпечує перехід від зовнішнього плану дій до внутрішнього. Виконання завдань сприяє розвитку уяви, мислення, уваги, пам'яті.

Блок 8. Резюме. Підведення коротких підсумків. Забезпечує зворотний зв'язок 3 учнями на уроці й передбачає якісну і емоційну оцінку самого уроку [8]. Під час уроку в учнів зберігається позитивна мотивація успіху та бажання перейти до наступного етапу роботи. Кожний етап уроку передбачає прийоми та методи ТРВ3, які стимулюють творче мислення учнів. У початкові школі на уроках математики використовують такі методи ТРВЗ: 
метод спроб і помилок, мозковий штурм, розв'язання суперечностей, алгоритм, ситуативні завдання: вправа Чорний ящик, метод фокальних об'єктів, системний оператор, типові прийоми фантазування, морфологічний аналіз «Чарівна доріжка», дихотомія (звуження кола пошуку) тощо [5, с. 13]. Розглянемо детальніше деякі з них: метод фокальних об'єктів передбачає перенесення властивостей одного предмета на інший. Прикладами застосування означеного методу можуть бути завдання типу: «Придумати щось нове, видозмінюючи або вдосконалюючи реальний об'єкт», «Ознайомити дітей з чимось новим або закріпити здобуті раніше знання, розглядаючи предмет у незвичному ракурсі», «Скласти розповідь або казку про об'єкт, який розглядається, використовуючи знайдені ознаки (повністю або частково)».

Типові прийоми фантазування (збільшення - зменшення, ділення - об'єднання, перетворення ознак часу, спеціалізація - універсалізація, прийом навпаки) у своїй основі мають активізацію мисленнєвої діяльності. На уроках математики ці прийоми можуть мати такий зміст:

- Чарівник «Плутанина» переплутав числа від 1 до 10. Допоможіть йому розставити їх у порядку зростання.

- Ігорю 5 років, він ходить у дитячий садок. Прийшов Чарівник «Подорож у часі» й переніс його на три роки вперед. Скільки років буде Ігорю і що він буде робити?

- Допоможіть Чарівнику «Зупинка часу» розв’язати задачу: Роману 5 років, а його товаришу Максиму 7 років. Прийшов Чарівник і зупинив час для Максима, а на Романа його чари не подіяли. Минуло 2 роки. Скільки років зараз Максиму? Скільки років Роману?

- Допоможіть Чарівнику «Об'єднання» об’єднати трикутники так, щоб утворився квадрат» тощо.

Морфологічний аналіз сприяє розвитку мислення та формуванню уміння знаходити безліч способів розв'язання проблеми. Робота розпочинається із «чарівної доріжки», по якій мандрує герой - цифра. Якщо в неї гарний настрій, обводимо iï червоним кольором, і це число збільшується, коли зустрічає на своєму шляху інші числа. Якщо настрій у цифри поганий - обводимо їі синім кольором, і тоді ми повинні це число відняти або поділити на це число:

$\begin{array}{llllllllll}\text { Гарний настрій } & 1 & 2 & 3 & 4 & 5 & 6 & 7 & 8 & 9 \\ \text { «Герой» } 2 & 3 & 4 & 5 & 6 & 7 & 8 & 9 & 10 & 11\end{array}$

Прийом «Лінійна дихотомія». Мета прийому полягає в тому, щоб закріпити поняття «до», «після», «між», «попереду». Учням можна запропонувати числа від 0 до 100, записані десятками $(0,10,20,30,40,50,60,70,80,90,100)$. Я задумала число і пропоную учням його відгадати за допомогою запитань і відповідей «так» або «ні»: Це число 50? (Нi). Це число від 50 до 100? (Ні). Це число менше ніж 50? (Так). Це число 20? (Нi). Це число більше 20? (Так). Це число між 20 і 40 ? (Так). Це число 30? (Так) [2, с. 22-24].

Компетентнісний підхід в освіті вимагає відходу від інформаційної спрямованості навчання і перенесення акценту з засвоєння нормативно визначених знань, умінь та навичок на формування й розвиток у школярів здатності самостійно практично діяти, застосовувати індивідуальний досвід та досягнення в нестандартних, творчих, життєвих ситуаціях. Технологія ТРВ3 є особливо актуальною в сучасних умовах розвитку освіти, оскільки забезпечує глибоке засвоєння фактичних знань, формує стиль мислення, спрямованого не на використання готових знань, а на їх генерацію. За умови цілеспрямованої систематичної діяльності вчителя ТРВЗ сприяє реалізації актуальної проблеми розвитку творчого 
потенціалу кожного школяра. Окремі елементи ТРВ3 можуть бути гармонійно поєднані 3 традиційними методами навчання, зокрема у процесі навчання математики. Ця технологія змушує будувати навчальний процес, у якому вчитель та учні перебувають у постійному творчому пошуку. Подальші розвідки стосуватимуться грунтовного вивчення методів і прийомів ТРВ3 у навчанні математики учнів молодшого шкільного віку.

\section{Література}

1. Альтшуллер Г. С. Как стать гением: Жизненная стратегия творческой личности / Г. С. Альтшуллер, И. М. Верткин. - Минск: Беларусь, 1994. - 480 с. 2. Гусарова Е. В. Решение задач на уроках математики с помощью ТРИЗ-технологий / Е. В. Гусарова // Вестник Пензенского государственного университета. - 2015. - № 1. - С. 22-26. 3. Ильницкая И. А. Проблемные ситуации как средство активизации мыслительной деятельности учащихся на уроке: [учеб. пособие к спецкурсу] / И. А. Ильницкая. - Пермь : Пермский государственный педагогический институт, 1983. - 76 с. 4. Курлова О. М. Використання елементів ТРВ3 на уроках математики, як засіб формування творчого мислення учнів: [метод. посібник]/ О. М. Курлова. - Первозванівка, 2013. - 46 с. 5. Макрідіна Л. О. Технологія творчості ТРВ3 / Л. О. Макрідіна // Управління школою. 2003. - № 32 - С. 12-26. 6. Навчальні програми для загальноосвітніх навчальних закладів із навчанням українською мовою. 1-4 класи. - Київ : «Освіта», 2011. - 392 с. 7. Савченко О. Компетентнісна спрямованість нових навчальних програм для початкової школи / О. Я. Савченко // Початкова школа. - 2012. - № 8. - С. 1-6. 8. Утёмов В. В. Структура креативного урока по развитию творческой личности учащихся в педагогической системе НФТМ-ТРИЗ [Электронный ресурс] / В. В. Утёмов, М. М. Зиновкина // Концепт. - 2013. Современные научные исследования. Выпуск 1.- ART 53572. - Режим доступу: http://ekoncept.ru/ 2013/53572.htm 9. Фадєєва Т. О. Інноваційні технології навчання математики у початкових класах / Т. О. Фадєєва: [навч.-метод. посібник для студ. психолого-педагогічного ф-ту пед. ун-ту] / Т. О. Фадеева. - Кіровоград : Авангард, 2011. - 95 с. 10. Фурман А. В. Теорія навчальних проблемних ситуацій : психолого-дидактичний аспект: [монографія]/ Анатолій Всильович Фурман. - Тернопіль : Астон, 2007. - 164 с.

УДК 51(07)

Сергій Семенець

\section{КОНЦЕПЦЯ РОЗВИВАЛЬНОГО НАВЧАННЯ МАТЕМАТИКИ: ДИДАКТИЧНА МОДЕЛЬ ОРГАНІЗАЦЇ̈ НАВЧАЛЬНО-МАТЕМАТИЧНОЇ ДІЯЛЬНОСТІ УЧНІВ}

Семенець С. П. Концепція розвивального навчання математики: дидактична модель організації навчально-математичної діяльності учнів.

У контексті особистісно-розвивального підходу проаналізовано методи навчання математики, створено нелінійну дидактичну модель організації навчально-математичної діяльності учнів. За результатами змістово-теоретичного аналізу та дидактичного моделювання розроблено розвивально-задачний метод навчання математики.

Ключові слова: дидактична модель, методи навчання, розвивально-задачний метод навчання математики.

Семенец С. П. Концепция развивающего обучения математике: дидактическая модель организации учебно-математической деятельности учащихся. 